cambios pragmáticos, esa dicotomía no tiene sentido, advirtiendo eso sí que, no por ello, se confunden sus diferencias simbólicas específicas a cada régimen de producción.

Vivir del fruto de su trabajo es el anhelo de todos los seres humanos. También lo es de los autores y artistas. En este sentido y al margen de la legítima decisión personal de cada cual a ejercer su derecho, insistir en promover la gratuidad de los bienes intangibles en una sociedad y economía mundial donde todo tiene precio es, por decir lo menos, anacrónico. Ha sido pues el propio desarrollo histórico el que ha abierto la posibilidad de salir de esa entelequia platónica que relegaba la obra artística a la trascendencia metafísica y al artista a la pobreza. En pocas palabras, el nuevo hábitat tecnológico, social y cultural impulsado por la globalización del pragmatismo, han conseguido que el trabajo intelectual y artístico, al igual que el técnico y manual, puedan deshacer esas viejas y lamentablemente todavía arraigadas injusticias.

Cuando se apela a un trato justo, se lo hace por tanto a la comprensión compleja de nuestra condición cultural e histórica. Querer mantener el modelo metafísico de cultura en el nuevo contexto económico y social se ha vuelto, cuando menos, problemático. De hecho, más allá de la información confusa que se entrega por los medios, es la propia comunidad la que exige un trato justo para sus autores y artistas y es ella misma la que no puede entender que los intermediarios entre las obras y el público insistan en culpar a los creadores por defender sus legítimas aspiraciones económicas por su trabajo. Es hora que la sensatez triunfe y todos juntos obtengamos lo que es justo, pues lo que está en juego es algo más que una ley y un principio de justicia: es nuestra propia dignidad como sociedad civil madura y equilibrada.

Gustavo M eza Wevar

Presidente

Sociedad de Autores $\mathrm{N}$ acionales de Teatro, Ciney Audiovisuales (ATN),

Chile

info@atn.cl

\title{
Derechos de autor: la nueva actitud
}

Antes de que aparecieran la sociedad global y los países emergentes, el mundo se estructuraba piramidalmente, o quizá siguiendo un formato bipolar. Éramos capitalistas o anticapitalistas, desarrollados o subdesarrollados, protagonistas o actores muy, muy secundarios. A partir de la revolución digital el mundo se ha interconectado. Y precisamente por la mayor homogeneidad tecnológica, política o económica, el tejido social ha dejado de ser visto como una sola cosa. Surgen las minorías, aparecen los contrastes, los relieves, las diferencias. No sólo quiere ser cada cual tratado de manera digna, sino que hay mayor rechazo a la discriminación. Desde el género, las mujeres no tienen ya más paciencia para la violencia doméstica ni para la discriminación laboral. Los homosexuales están hartos de 
ser considerados seres humanos de segunda. Las diversas razas reclaman, con toda razón, contra las actitudes o leyes racistas. Se habla de los derechos de los niños, de los inmigrantes, de las temporeras, de los estudiantes, de los clientes... No se trata de derechos que deban pedirse sólo en los momentos «adecuados». Hemos dejado atrás las luchas estructuradas donde las necesidades de cada cual serían resueltas algún día más adelante, cuando fuera oportuno. La gente conoce mejor sus deberes y, al mismo tiempo, quiere sus derechos ahora.

Los autores somos también una minoría, y una minoría que muchísimas veces ha sido tratada de manera despectiva, sin consideración alguna. El pirateo, el no pago de derechos, el basureo por parte de las empresas, la sensación persistente de que la propiedad intelectual no existe o no vale y de que la creación de obras es un hecho fortuito que no vale la pena comentar, y la siempre novedosa recolección de argumentos para no pagar ni pedir autorización, son malas costumbres, actos discriminatorios.

Hemos entrado -también en el ámbito del derecho de autor- en una nueva era de actitudes más firmes. Crear una obra es hacer más ancho el mundo, añadirle algo, poner valor en él. Mientras más éxito consiga esa obra -trátese de una canción, una película, un poema, un dibujo- más rico se hace el mundo. Pues bien, los autores deben ser parte de esa riqueza, deben estar siempre asociados al éxito -o al fracaso- de sus obras. Si la obra consigue un espectador, pues bien, el autor recaudará doscientos pesos. Si consigue un millón, lo correcto es que recaude doscientos millones. Por cada éxito, saben muy bien los autores e intérpretes, atrás han quedado muchos fracasos y muchas acciones no rentables.

Aunque se haya implantado una cultura de la irresponsabilidad, de falta de respeto a los derechos de autor (cultura de la que casi todos formamos parte), no está bien que se disfrute y se lucre sistemáticamente de unas obras a espaldas de los autores. Muchos autores lo entienden así, y están dispuestos a dar la pelea por sus derechos, por un trato justo. Han pasado los años, y para la misma actitud mezquina y ciega de negarles a los autores lo que les pertenece, surgen nuevos argumentos y nuevos contextos.

La cultura digital le trae a los autores dos buenas novedades: mayor difusión y formas más directas de acceso a las audiencias. Pero al mismo tiempo, en la nube digital los derechos de autor se evaporan más fácilmente. Los creadores observamos cómo se organizan grandes negocios a partir de unas obras por las cuales finalmente nadie paga. Internet debiera estar regulado de tal manera que los autores perciban lo que les corresponde.

Se trata a veces a los autores, con muy mala intención, de aprovechadores, de sanguijuelas, etc., sólo porque pretenden defender lo que les pertenece: el uso de obras creadas por ellos. Es más divertido (para otros) pensar en que la creación intelectual es un hecho gracioso que se da espontáneamente y que debe ir a formar parte del patrimonio de la humanidad sin pasar previamente por el mercado. Otros, desde la filantropía teórica, quieren aplicarle a los autores la obligación de regalar sus obras por razones de equidad social: es que se trata de fines educacionales, de audiencias de menores recursos, etc. Los creadores tenemos por lo general muy desarrollado el sentido de la justicia, y a menudo luchamos 
por una mayor igualdad entre las personas. Eso no implica que debamos subvencionar nosotros lo que es una obligación de la sociedad.

También se pretende luchar contra los creadores atacando a las sociedades de gestión colectiva, sembrando dudas infundadas sobre su funcionamiento, y equiparándolas -con ligereza- a las grandes multinacionales. Los autores en solitario pueden hacer muy poco. La sociedad debe acostumbrarse a que los grupos organizados -en este caso los autores- son parte relevante de la vida ciudadana.

Por último, hay argumentaciones anti derechos de autor que arrancan desde las costumbres más primitivas del Chile subdesarrollado. Piratear o no pagar derechos simplemente porque somos el país que somos, porque aquí entre nosotros es más divertido tijeretear, hacer "perro muerto", descargar y distribuir lo que caiga, etc. O sea, sumar nuevos derechos, pero no nuevos deberes.

Los derechos de autor no son un tema de mañana. Son cada vez más los creadores para los cuales sus derechos son algo que se defiende hoy, en lo pequeño y en lo grande, en todos los casos, en el mundo digital y en el no digital, en las diversas formas de la creación intelectual, ante unas u otras audiencias. Asumir esta realidad implica un cambio cultural y una mayor apertura mental.

Juan Guillermo Tejeda

Facultad de A rquitectura y U rbanismo, Universidad de Chile,

Chile

tejeda@uchile.cl 